\title{
PEMENUHAN KEBUTUHAN MAKANAN POKOK BAGI MASYARAKAT TERDAMPAK COVID 19 DI KABUPATEN NGANJUK
}

\author{
Lutfi Saksono', Yunanfathur Rahman², Ajeng Dianing Kartika ${ }^{3}$ \\ ${ }^{1}$ Universitas Negeri Surabaya \\ ${ }^{2}$ Universitas Negeri Surabaya \\ ${ }^{3}$ Universitas Negeri Surabaya \\ lutfisaksono@unesa.ac.id,y.rahman@unesa.ac.id, ajengkartika@unesa.ac.id
}

\begin{abstract}
Abstrak
Wabah yang diakibatkan oleh virus corona atau Covid 19 ditetapkan oleh Organisasi Kesehatan Dunia PBB sebagai pandemi. Artinya penyakit ini telah menjadi wabah global yang menyerang banyak tempat dan negara, termasuk Indonesia. Keresahan muncul di masyarakat, karena dampak penyakit ini tidak hanya pada kesehatan tetapi juga ekonomi. Tentu saja dampak ekonomi sangat dirasakan oleh masyarakat miskin di kota maupun di desa. Pemenuhan kebutuhan pokok agar bisa bertahan hidup merupakan hal yang sangat penting. Oleh sebab itu beberapa pihak memiliki empati untuk membantu masyarakat memenuhi kebutuhannya di masa pandemi ini. Salah satu bentuk pengabdian masyarakat di masa pandemi adalah penyaluran bantuan sembako untuk masyarakat miskin. Beberapa warga di desa-desa di Kecamatan Rejoso Kabupaten Nganjuk yang merupakan mitra KKN Unesa masih berada di bawah garis kemiskinan dan terdampak pandemi covid-19. Bagi mereka pandemi ini semakin memperberat beban mereka untuk memenuhi kebutuhan pokok, seperti beras, minyak goreng, gula dan lain sebagainya. Melalui pengabdian masyarakat ini Unesa menyalurkan bantuan 400 paket makanan yang dapat digunakan untuk memenuhi kebutuhan selama beberapa hari.
\end{abstract}

Kata Kunci : Covid 19, dampak ekonomi, makanan pokok

\section{PENDAHULUAN}

Akhir tahun 2019 China dikejutkan oleh virus corona yang menjangkiti salah satu kota besarnya, Wuhan, di Provinsi Hubei. Virus ini menyerang banyak orang di Kota Wuhan. Tingkat infeksinya jauh lebih tinggi daripada flu biasa dan Middle East Respiratory Syndrome (MERS) di tahun 2012 (ADB Briefs, 2020). Pemerintah China terpaksa membangun rumah sakit baru dalam waktu singkat, karena rumah sakit yang ada sudah tidak mampu menampung penderita yang semakin hari semakin banyak.
Salah satu cara untuk memutus mata rantai persebaran covid-19 di China adalah dengan cara mengisolasi Kota Wuhan. Akses keluar dan masuk ke Kota Wuhan dibatasi. Hanya pihak yang memiliki kepentingan dengan penanganan wabah saja yang boleh keluar dan masuk Kota Wuhan.

Namun tidak ada yang menyangka bahwa virus ini ternyata sudah menyebar ke mana-mana. Waktu yang dibutuhkan tidak lama bagi virus ini untuk menyebar ke beberapa negara di Eropa, Asia dan Amerika. Persebaran yang cepat dan banyaknya daerah yang terjangkiti membuat Organisasi Kesehatan Dunia (World Health Organization) 
meningkatkan status kesehatan dunia yang sebelumnya endemik menjadi pandemi. Artinya virus corona telah menjadi wabah global. Tidak hanya di China atau Asia saja, tetapi sudah tersebar ke seluruh benua.

Tingkat penyebaran yang cukup cepat ini sangat mengkhawatirkan. Apalagi belum ada vaksin anticorona dan obat yang tepat untuk menyembuhkan penderita (Yanti, 2020). Oleh sebab itu beberapa negara di dunia mengambil kebijakan yang tidak populer. Dalam ASEAN Policy Brief (2020) ditegaskan ada langkah-langkah mitigasi yang perlu diterapkan, seperti jaga jarak (social distancing); penutupan sementara sekolah, kantor, dan beberapa bisnis yang tidak terlalu penting; kunjara (lockdown), dan karantina. Tentu saja langkah-langkah ini berdampak pada kegiatan ekonomi, seperti penghentian produksi dan operasional bisnis, dan pembatasan pergerakan orang yang mengakibatkan kerugian bisnis dan hilangnya mata pencaharian dan pendapatan bagi pekerja.

Persebaran covid-19 mengancam kehidupan, kesejahteraan, keamanan dan kehormatan manusia secara global. Covid-19 memang sebuah pandemi yang tidak hanya dihadapi oleh Indonesia, tetapi penanganan wabah ini bersifat lokal (Dwinantoaji $\mathrm{H}$ et al, 2020). Oleh sebab itu sama dengan beberapa negara di ASEAN Pemerintah Indonesia mengambil kebijakan yang tidak populer yang disesuaikan dengan kepentingan dan kebutuhan Indonesia. Kegiatan pendidikan, perkantoran, perindustrian, transportasi dan sektor lainnya di Indonesia dibatasi bahkan beberapa sektor berhenti total.

Keadaan seperti ini membuat covid-19 bukan hanya menjadi masalah di sektor kesehatan di Indonesia, tetapi juga menjadi masalah besar bagi perekonomian Indonesia. Sektor ekonomi Indonesia terpuruk akibat adanya beberapa pembatasan kegiatan sosial dan ekonomi di masyarakat.

Bagi Indonesia dampak ekonomi akan sangat besar dan banyak orang akan terjerumus ke dalam kemiskinan. Tingkat pertumbuhan ekonomi tahun 2020 diproyeksikan dari sekitar
$5 \%$ menjadi antara $4,2 \%$ dan $-3,5 \%$. Diperkirakan tingkat kemiskinan juga akan meningkat dari $9.2 \%$ pada bulan September 2019 menjadi $9,7 \%$ pada akhir tahun2020. Situasi ini berpotenci akan mendorong 1,3 juta lebih banyak orang ke kemiskinan. Skenario terburuknya, tingkat kemiskinan akan meningkat menjadi 16,6\%, hampir setara dengan tahun 2004 ketika tingkat kemiskinan di angka $16,7 \%$. Ini berarti bahwa 19,7 juta lebih orang akan menjadi miskin (Suryahadi et al, 2000).

Covid-19 memang mempengaruhi ekonomi Indonesia. Namun di sisi lain pandemi covid-19 dapat membangun solidaritas di masyarakat (Supriatna, 2020). Memang di awal covid-19 masuk ke Indonesia ada sebagian masyarakat yang menganggap covid-19 merupakan aib. Stigma ini berlanjut pada pengusiran petugas kesehatan dari rumah kontrakan dan penolakan pemakaman jenazah korban covid-19 oleh sebagian warga (Yanti, 2020). Tetapi lambat laun kasus-kasus seperti di atas hilang setelah beberapa pihak melakukan pendekatan dan sosialisasi kepada masyarakat. Selanjutnya yang muncul adalah solidaritas sosial.

Solidaritas tersebut dapat dilihat melalui gerakan penggalangan dana dan bantuan barang baik yang dikelola oleh lembaga pemerintah maupun pihak swasta. Bantuan tidak hanya ditujukan kepada lembaga kesehatan dan tenaga medis saja, tetapi juga kepada masyarakat yang terdampak secara ekonomi.

Dampak ekonomi tidak hanya dirasakan oleh masyarakat di kota, tetapi juga dirasakan oleh masyarakat miskin di pedesaan. Berbagai upaya telah dilakukan Pemerintah Indonesia melalui jaring pengaman sosial untuk membantu perekonomian masyarakat yang terdampak covid-19. Pemerintah secara serius memberikan stimulus paket ekonomi dan telah melakukan berbagai upaya untuk membantu perekonomian masyarakat melalui berbagai kebijakan (Susilawati, 2020). Paket tersebut antara lain 1) bantuan langsung tunai (BLT); 2) bantuan pangan non-tunai (BPNT); 3) program keluarga 
harapan (PKH); dan 4) sembako baik dari APBN maupun APBD.

Selain pemerintah pusat dan pemerintah daerah, lembaga lain, seperti perguruan tinggi, juga turut membantu meringankan beban masyarakat. Salah satu perguruan tinggi yang turut membantu pemerintah adalah Universitas Negeri Surabaya (Unesa). Unesa menilai masyarakat perlu dibantu untuk meringankan beban hidupnya melalui bantuan makanan pokok.

Menurut Organisasi Pangan Dunia (FAO) makanan pokok merupakan makanan yang dikonsumsi secara rutin pada jumlah tertentu dan merupakan bagian dominan dalam pola makan serta merupakan sumber asupan energi dan gizi utama yang dibutuhkan (Prabowo, 2014). Berdasarkan definisi FAO tersebut makanan pokok merupakan makanan utama yang sangat dibutuhkan oleh kelompok masyarakat. Jika bahan makanan pokok ini berkurang atau hilang, maka akan berpengaruh terhadap asupan energi dan gizi masyarakat.

Makanan pokok bagi sebagian besar masyarakat Indonesia adalah beras. Oleh sebab itu, pemerintah Indonesia selalu menjaga pasokan dan stabilitas harga beras. Untuk saat ini dan mungkin dalam waktu yang cukup lama beras belum dapat disubstitusi oleh makanan lain sebagai makanan pokok orang Indonesia. Bahkan konsumsi beras menunjukkan tren meningkat (Sugiyanto, 2006). Baik di perkotaan maupun di pedesaan di Indonesia beras telah menjadi bahan makanan pokok. Keadaan ini menyebabkan komoditas beras memiliki nilai yang sangat strategis, karena menguasai hajat hidup orang banyak dan dapat dijadikan ukuran stabilitas ekonomi dan sosial Indonesia (Rohman \& Maharani, 2017).

Sebagai bahan makanan pokok bantuan beras sangat dinantikan oleh masyarakat miskin. Tujuan bantuan tersebut adalah untuk meringankan beban masyarakat miskin dan tetap menjamin keberlangsungan hidup mereka melalui ketersediaan makanan pokok di masa pandemi covid-19. Melalui kegiatan pengabdian kepada masyarakat Unesa menyalurkan bantuan makanan pokok ke desa-desa di Kecamatan Rejoso Kabupaten Nganjuk, karena selama ini desa-desa tersebut merupakan mitra kuliah kerja nyata (KKN) Unesa.

\section{METODE}

Langkah-langkah yang dilakukan dalam kegiatan pengabdian kepada masyarakat ini adalah sebagai berikut: 1) sosialisasi dan analisis situasi masyarakat. Kegiatan ini merupakan cara untuk mengetahui kondisi masyarakat dan menentukan khalayak sasaran penerima bantuan makanan pokok. Pengumpulan data melalui wawancara langsung kepada perangkat desa, tokoh masyarakat, calon mitra pengadaan dan penyaluran (toko dan warung) dan beberapa warga miskin di desa. 2) Data yang terkumpul selanjutnya diolah oleh tim. Dari kegiatan ini dapat diketahui jumlah makanan pokok yang harus disalurkan ke desa berdasarkan kriteria yang sudah ditetapkan. Serta dapat ditentukan mitra pengadaan dan penyaluran di desa tersebut yang dapat menyediakan pasokan makanan pokok sesuai standard yang telah ditetapkan. 3) Sosialisasi dan distribusi bantuan. Setelah mitra sasaran dan mitra pengadaan dan penyaluran ditetapkan, maka langkah selanjutnya adalah penyaluran bahan makanan pokok. Penyaluran diawali dengan sosialisasi tentang program-program pemerintah dan pola hidup sehat yang dilakukan oleh perangkat desa dan tim pengabdian kepada masyarakat.

\section{HASIL DAN PEMBAHASAN}

Untuk membantu meringankan beban masyarakat di tengah pandemi covid-19 dan mendorong masyarakat untuk berjuang bersamasama melawan covid-19, maka kegiatan pengabdian kepada masyarakat Unesa difokuskan pada pemberdayaan ekonomi masyarakat dan pemberian bantuan secara langsung.

Pemberdayaan ekonomi masyarakat diarahkan kepada kegiatan usaha mikro, kecil dan menengah (UMKM) yang terdampak covid-19 sehingga mempengaruhi kegiatan ekonomi mereka baik secara operasional maupun finansial. Pemberdayaan yang diberikan berupa pengetahuan tentang peluang usaha di tengah pandemi. UKMK yang Ekonomi, Sosial, dan Budaya

1084 
diberdayakan adalah UKMK yang menghasilkan produk-produk untuk pencegahan dan penanganan covid-19, seperti alat pelindung diri (APD), minuman herbal (jamu) dan hand sanitizer. Unesa membantu UMKM ini memasarkan produk ke masyarakat.

Sedangkan kegiatan pemberian bantuan secara langsung diarahkan pada pemberian bantuan makanan pokok kepada masyarakat baik yang ada di kota maupun yang ada di pedesaan. Pemberian bantuan makanan pokok ini bertujuan untuk mengatasi masalah pangan yang diakibatkan oleh menurunnya daya beli dan juga lonjakan harga bahan makanan.

Kegiatan pengabdian kepada masyarakat di Kecamatan Rejoso Kabupaten Nganjuk ini merupakan kegiatan pemberian bantuan secara langsung kepada masyarakat. Langkah pertama yang dilakukan dalam kegiatan pengabdian kepada masyarakat ini adalah sosialisasi program kepada masyarakat dan analisis situasi masyarakat. Masyarakat perlu mendapat penjelasan bahwa kegiatan pengabdian kepada masyarakat ini bertujuan untuk membantu masyarakat yang terdampak covid-19.

Sebagai salah satu lembaga pemerintah yang bergerak di bidang pendidikan tinggi, Unesa menjalankan fungsinya utamanya di bidang pendidikan, penelitian dan pengabdian kepada masyarakat atau biasa disebut kegiatan tridarma perguruan tinggi. Fungsi utama di bidang pengabdian kepada masyarakat menunjukkan bahwa perguruan tinggi tidak boleh lepas dan jauh dari masyarakat. Oleh sebab itu pengabdian kepada masyarakat di tengah bencana seperti pandemi covid-19 ini memang harus dilakukan oleh Unesa. Apalagi pandemi ini memiliki dampak yang luar biasa bagi masyarakat, terutama dampak ekonomi. Sosialisasi dilakukan kepada perangkat desa dan masyarakat di desa-desa yang pernah menjadi mitra kuliah kerja nyata (KKN) Unesa di Kecamatan Rejoso Kabupaten Nganjuk.

Kecamatan Rejoso berada pada titik koordinat antara garis lintang (latitude) -7.504866 dengan titik 111.876766 garis bujur (longitude).
Dengan jumlah total penduduk sebanyak 68.832 jiwa, terdiri dari 34.098 jiwa laki-laki dan 34.734 jiwa perempuan. Kecamatan Rejoso memiliki 24 wilayah desa, yaitu 1) Desa Banjarejo; 2) Desa Benda Asri; 3) Desa Gempol; 4) Desa Jatirejo; 5) Desa Jintel; 6) Desa Kedung Padang; 7) Desa Klagen; 8) Desa Mlorah; 9) Desa Mojorembun; 10) Desa Mungkung; 11) Desa Musir Kidul; 12) Desa Musir Lor; 13) Desa Ngadiboyo; 14) Desa Ngangkatan; 15) Desa Puh Kerep; 16) Desa Rejoso; 17) Desa Sambi Kerep; 18) Desa Setren; 19) Desa Sidokare; 20) Desa Sukorejo; 21) Desa Talang; 22) Desa Talun; 23) Desa Tritik dan 24) Desa Wengkal. Dari 24 desa tersebut hanya 10 desa yang merupakan mitra KKN Unesa, yaitu 1) Desa Jatirejo; 2) Desa Jintel; 3) Desa Mlorah; 4) Desa Mojorembun; 5) Desa Mungkung; 6) Desa Ngangkatan; 7) Desa Ngadiboyo; 8) Desa Talun; 9) Desa Tritik dan; 10) Desa Wengkal.

Pada tahapan kegiatan sosialisasi dan analisis situasi masyarakat ini tim pengabdian kepada masyarakat melakukan koordinasi dan sosialisasi dengan pihak sasaran di 10 desa di Kecamatan Rejoso. Kegiatan ini dilakukan bersama perangkat dari sepuluh desa tersebut. Tujuannya adalah untuk menentukan lapisan masyarakat yang akan menerima bantuan paket makanan pokok, terutama lapisan masyarakat yang belum tersentuh bantuan pemerintah atau lapisan masyarakat yang benarbenar membutuhkan bantuan meskipun sudah mendapat bantuan dari pemerintah.

Mereka yang berhak memperoleh bantuan makanan pokok adalah mereka yang sesuai dengan kriteria sebagai berikut: 1) keluarga miskin yang tidak menerima bantuan dari pemerintah pusat dan atau pemerintah daerah; 2) keluarga miskin yang sudah menerima bantuan dari pemerintah tetapi memiliki anggota keluarga yang banyak sehingga bantuan tersebut cepat habis; 3) kepala keluarga atau anggota keluarga yang menderita sakit kronis dan menahun; 4) pekerja lepas harian yang mengalami penurunan pendapatan sangat drastis selama pandemi covid-19 dan; 5) kepala keluarga yang mengalami pemutusan hubungan kerja (PHK) pada masa pandemi covid-19 dan tidak memperoleh pesangon yang cukup.

Ekonomi, Sosial, dan Budaya 1085 
Pada tahapan kegiatan ini juga dilakukan pendataan terhadap mitra yang dapat bekerjasama dalam penyaluran bahan makanan pokok kepada mitra sasaran. Mitra pengadaan dan penyaluran ini harus memiliki usaha menjual bahan makanan pokok dan harus berasal dari desa yang sama dengan mitra sasaran. Mitra pengadaan dan penyaluran ditentukan berdasarkan kemauan dan kesanggupan mereka untuk mengadakan barang, melakukan pengepakan (packaging) dan penyaluran. Penentuan mitra pengadaan dan penyaluran ini juga bertujuan untuk memberdayakan pelaku usaha di desa-desa tersebut sehingga mereka memperoleh pendapatan tambahan dari hasil kerjasama dengan tim pengabdian kepada masyarakat Unesa.

Dari kegiatan sosialisasi dan analisis situasi masyarakat yang dilakukan oleh tim pengabdian kepada masyarakat Unesa bersama perangkat masing-masing desa, maka dipilihlah 400 mitra sasaran yang berhak mendapatkan bantuan makanan pokok. Selain mitra sasaran dari sepuluh desa, ada 20 mitra pengadaan dan penyaluran yang dipilih untuk melakukan pengadaan dan pendistribusian bantuan makanan.

Tabel 1. Desa dan mitra sasaran

\begin{tabular}{ccc}
\hline Desa & Mitra sasaran & $\begin{array}{c}\text { Mitra } \\
\text { Pengadaan }\end{array}$ \\
\hline Jatirejo & 40 & 2 \\
Jintel & 40 & 2 \\
Mlorah & 45 & 2 \\
Mojrembung & 35 & 2 \\
Mungkung & 40 & 2 \\
Ngangkatan & 40 & 2 \\
Ngadiboyo & 35 & 1 \\
Talun & 35 & 2 \\
Tritik & 45 & 2 \\
Wengkal & 45 & 2 \\
\hline
\end{tabular}

Pada tahapan ini juga ditentukan jenis makanan pokok dan makanan tambahan atau bahan makanan lainnya yang dikemas dalam satu paket. Tentu saja jenis makanan tersebut harus sesuai dengan kebutuhan mitra sasaran. Makanan pokok yang diberikan adalah beras sebanyak $5 \mathrm{~kg}$, sedangkan tambahannya berupa gula pasir $2 \mathrm{~kg}, 1$ pouch kecap, 1 pouch saos sambal, minyak goreng 2 liter, 1 kotak teh celup dan 5 mie instan. Barang-barang tersebut telah ada di toko atau warung yang dijadikan mitra pengadaan dan penyaluran oleh tim pengabdian kepada masyarakat. Barang yang dikemas dan akan disalurkan harus memiliki masa kadaluwarsa yang lama.

Setelah penetapan mitra sasaran dan mitra pengadaan dan penyaluran, maka kegiatan selanjutnya adalah kegiatan sosialisasi dan distribusi bantuan makanan pokok kepada mitra sasaran yang ada di sepuluh desa. Distribusi makanan pokok memang dilakukan oleh mitra pengadaan dan penyaluran, tetapi tim pengabdian kepada masyarakat dan perangkat desa juga mengikuti kegiatan pendistribusian secara langsung. Hal ini dilakukan untuk memastikan bahwa paket bahan makanan benar-benar diterima oleh mitra sasaran yang telah ditetapkan.
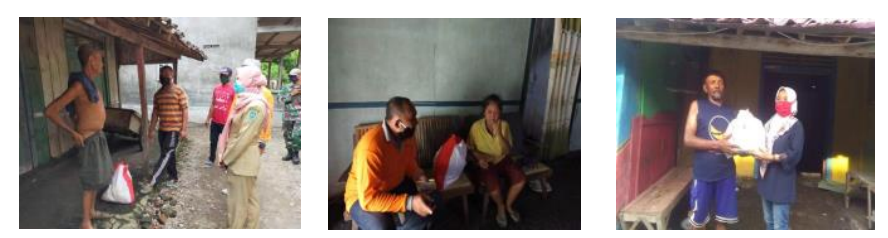

Gambar 1 Distribusi paket makanan pokok ke warga

Proses distribusi tidak hanya sekedar memberikan bantuan paket bahan makanan saja, tetapi juga dilakukan kegiatan sosialisasi pencegahan penularan covid-19 dan penerapan pola hidup bersih dan sehat (PHBS) oleh tim pengabdian kepada masyarakat dan petugas dari desa. Melalui kegiatan ini diharapkan masyarakat sadar akan pentingnya kesehatan dan tidak menganggap remeh covid-19. Salah satu penyebab cepatnya penyebaran virus ini adalah kesadaran masyarakat yang rendah serta sikap yang cenderung tidak peduli pada wabah ini.

Pada saat proses distribusi tim pengabdian kepada masyarakat melakukan pengamatan dan wawancara kepada mitra sasaran. Hasilnya, mitra sasaran menyampaikan bahwa kegiatan pemberian bantuan makanan pokok ini sangat penting bagi masyarakat miskin dan dapat membantu

$$
\text { Ekonomi, Sosial, dan Budaya }
$$

1086 
meringankan beban mereka. Selain itu mereka tidak perlu lagi belanja kebutuhan pokok untuk beberapa hari, sehingga mereka bisa menyisihkan uang untuk kebutuhan lain.

Mitra sasaran juga menyatakan bahwa makanan pokok yang diberikan kualitasnya jauh lebih baik daripada makanan pokok yang mereka beli sehari-hari. Kualitas ini tampak dari merek barang dan harga barang yang lebih baik. Biasanya mitra sasaran memilih membeli bahan makanan yang harganya lebih murah. Sedangkan secara kuantitas, bantuan yang diterima oleh mitra sasaran juga diakui lebih banyak dibanding bantuan paket makanan yang diberikan oleh pihak lain. Mitra sasaran sangat mengapresiasi kegiatan yang dilakukan oleh tim pengabdian kepada masyarakat dari Unesa.

Kegiatan pengabdian kepada masyarakat Unesa ini juga memberi manfaat kepada mitra pengadaan dan penyaluran yang ada di sepuluh desa di Kecamatan Rejoso Kabupaten Nganjuk. Setidaknya ada 19 toko atau warung yang dijadikan mitra pengadaan dan penyaluran. Manfaat yang diperoleh adalah meningkatnya pendapatan mereka.

Kegiatan ini tidak hanya memberi manfaat kepada masayarakat desa, tetapi juga memberi manfaat bagi pelaksana pengabdian kepada masyarakat di lapangan dan juga mahasiswa yang menjadi relawan untuk meningkatkan solidaritas sosial baik di saat normal maupun ada bencana.

\section{KESIMPULAN}

Pengabdian kepada masyarakat yang dilaksanakan oleh Universitas Negeri Surabaya di 10 desa di Kecamatan Rejoso Kabupaten Nganjuk ini bertujuan untuk meringankan beban masyarakat pedesaan di tengah pandemi covid-19. Ada 400 paket makanan yang disalurkan di 10 desa. 10 desa tersebut merupakan desa mitra kkn Unesa yang memiliki warga terdampak pandemi covid-19 di sektor ekonomi. Pandemi ini memang tidak hanya mempengaruhi aspek kesehatan di sebuah negara, tetapi juga memiliki pengaruh yang signifikan terhadap ekonomi masyarakat. Di Indonesia beberapa lini bisnis terganggu bahkan harus ditutup, banyak orang kehilangan pekerjaan dan angka kemiskinan berpotensi meningkat. Salah satu cara untuk menanggulangi masalah sosial tersebut adalah pemenuhan makanan pokok bagi masyarakat di pedesaan. Bantuan makanan pokok sangat penting bagi masyarakat karena makanan pokok merupakan kebutuhan utama masyarakat dan substitusinya susah dicari. Di sisi lain pemberian bantuan ini untuk meningkatkan solidaritas sosial di tengah bencana, sehingga bisa menjadi warisan yang baik bagi generasi masa depan.

\section{UCAPAN TERIMAKASIH}

Ucapan terimakasih kami sampaikan kepada Rektor Universitas Negeri Surabaya, Prof. Dr. Nurhasan, M.Kes., yang telah menginisiasi kegiatan pengabdian kepada masyarakat penugasan dalam rangka percepatan penanganan Covid-19 di beberapa daerah di Jawa Timur. Ucapan terima kasih juga disampaikan kepada Prof. Dr. Darni, M.Hum., ketua LPPM Unesa yang telah mendorong beberapa dosen untuk terlibat secara aktif membangun solidaritas sosial melalui pengabdian kepada masyarakat di tengah merebaknya wabah virus corona 19. Terima kasih juga disampaikan kepada Pemerintah Kabupaten Nganjuk dan masyarakat Nganjuk yang telah mendukung dan memfasilitasi kegiatan ini.

\section{REFERENSI}

ADB Briefs. 2020. The Economics Impact Of Covid-19 Outbreak on Developing Asia.

ASEAN Policy Brief. (2020). Economic Impact of COVID-19 Outbreak on ASEAN.

Dwinantoaji, Hastoro \& Sumarni DW. (2020) Human Security, Social Stigma, and global health: the covid-19 Pandemic in Indonesia. Journal of the Medical Sciences. 52 (3). 74-81.

Prabowo, Dwi Wahyuniarti. (2014). Pengelompokan Komoditi Bahan Pangan Pokok dengan Metode Analytical Hierarchy Process. Buletin Ilmiah Litbang Perdagangan. 8 (2): 163182.

Rohman, Abdul \& Artita Devi Maharani. 2017. Proyeksi Kebutuhan Konsumsi Pangan Beras di Daerah Istimewa Yogyakarta. Journal of Sustainable Agriculture. 32 (1). 29-34.

Ekonomi, Sosial, dan Budaya 1087 
Supriatna, Encup. (2020). Socio-Economic Impacts of The COVID-19 Pandemic: The Case of Bandung City. Journal of Governance, 5 (1): 61 70 .

Sugiyanto, Catur. 2006. Permintaan Beras di Indonesia: Revisited. Jurnal Ekonomi dan Bisnis Indonesia. 21 (2). 138-155.

Susilawati, Falefi Reinfal, \& Purwoko Agus. (2020). Impact of COVID-19's Pandemic on the Economy of Indonesia. Budapest International
Research and Critics Institute (BIRCI-Journal). 3 (2): 1147-1156

Suryahadi, Asep, et al. (2020) Estimating The Impact of Covid-19 on Poverty in Indonesia. Bulletin of Indonesian Economic Studies. 56 (2): 175-192.

Yanti, Budi et al. (2020) Community Knowledge, Attitudes and Behavior Towards Social Distancing Policy as a Means of Preventing Transmission of Covid-19 in Indonesia. Jurnal Administrasi Kesehatan Indonesia. 8 (1): 4-14. 